\title{
EXPERIMENTAL VERIFICATIONS AND NUMERICAL THERMAL SIMULATIONS OF AUTOMOBILE LAMPS
}

\author{
EKSPERIMENTALNA PREVERJANJA IN NUMERIČNE TOPLOTNE \\ SIMULACIJE AVTOMOBILSKIH ŽAROMETOV
}

\author{
Michal Guzej, Jaroslav Horsky \\ Brno University of Technology, Faculty of Mechanical Engineering, Technicka 2, 61669 Brno, Czech Republic \\ guzej@1ptap.fme.vutbr.cz \\ Prejem rokopisa - received: 2014-07-31; sprejem za objavo - accepted for publication: 2015-05-21
}

doi:10.17222/mit.2014.149

\begin{abstract}
Over the last decade lamps became a design feature of a car body and to preserve their primary purpose they are much more complex than in the past. Today's car lamps contain powerful light sources, which utilize new technologies such as dot-concentrated light (LED chips or xenon discharge tubes). One of the unfavourable properties of these products is a high amount of thermal energy produced in a small area, causing a high thermal stress on the components. For this reason, it is important to know the temperature in critical locations to avoid damaging the lamp body or causing a defect in the light source itself. This paper presents the results of a numerical simulation of the working conditions of a lamp, the measurement inside the environmental-simulation chamber with a real lamp, providing the same conditions and the verification of the simulation results with the measurement, which confirmed the precision of the numerical simulation. The verification procedure was developed at the Heat Transfer and Fluid Flow Laboratory of the BUT in partnership with Skoda Auto a.s.

Keywords: automobile lamps, thermocouples, numerical simulation, thermal measurements, verification
\end{abstract}

Zadnje desetletje so avtomobilski žarometi postali del oblikovanja avtomobilske karoserije in za ohranitev prvotne vloge so, v primerjavi s preteklostjo, postali bolj kompleksni. Današnji avtomobilski žarometi imajo močan izvor svetlobe, ki uporablja nove tehnologije, kot je točkasto skoncentrirana svetloba (LED čip ali ksenonska razelektritvena cev). Ena od neželjenih lastnosti teh proizvodov je velika količina toplotne energije, ki nastane na majhnem področju in zaradi tega pride do večje termične napetosti v komponentah. Zato je pomembno poznati temperature na kritičnih lokacijah, da se prepreči poškodba ohišja žarometa ali da nastane napaka na samem izvoru svetlobe. Članek predstavlja rezultate numerične simulacije delovnih pogojev žarometov, meritve $\mathrm{v}$ notranjosti numerično simuliranega okolja realnega žarometa $\mathrm{z}$ realno žarnico in preverjanje rezultatov simulacije $\mathrm{z}$ meritvami, ki so potrdile natančnost numerične simulacije. Postopek verifikacije je bil razvit y Laboratoriju za prenos toplote in tok fluidov na BUT, s sodelovanjem Skoda Auto a.s.

Ključne besede: avtomobilski žarometi, termoelementi, numerična simulacija, toplotne meritve, preverjanje

\section{INTRODUCTION}

Modern automobile lamps have a complex body design and contain powerful built-in sources of light. This can create problems for the materials used for their construction. ${ }^{1}$ Manufacturers and consumers, in this case Škoda Auto a.s., need to know the temperature generated at critical locations and compare it with the temperature limit for each plastic material. Every material has a long-term temperature limit and a short-term temperature limit. ${ }^{2}$ Electrical losses of dot-concentrated light are converted into thermal energy. The result of this effect is a temperature gradient, which produces significant thermal stresses within the structure. ${ }^{3}$ Solving this problem with an analytical method is a formidable task. The few solutions available cover only simple structural shapes. The only option is to use simulation software such as ANSYS, COMSOL, etc. Verifying the results of a computer simulation is always necessary when high precision is required. Experimentation under the same conditions as in the simulation determines the accuracy of the results or detects possible errors in the settings of the simulation model. Wire thermocouples built into control points are used for the temperature measurement. Deviations between the simulation and reality are determined from the heat-settled part of the experiment.

\section{EXPERIMENTAL PART}

To numerically simulate an automotive lamp (Figure 1), the ambient temperature during the experiment must be known. A lamp placed inside an environmental simulation chamber (type: MK 720 E3.1) manufactured by Binder was used for this purpose. This device can maintain the required temperature by forced convection in a very small range.

\subsection{Description of the measurement circuit}

Data collection during the experiments consists of five major parts (Figure 2). First, data is measured through the thermocouples. Then, information in millivolts is transferred into a 7001 switch system manufactured by Keithley, an American company. This model is a half-rack, high-density, two-slot mainframe with a maximum of 80 signal channels (in this experiment, 12 


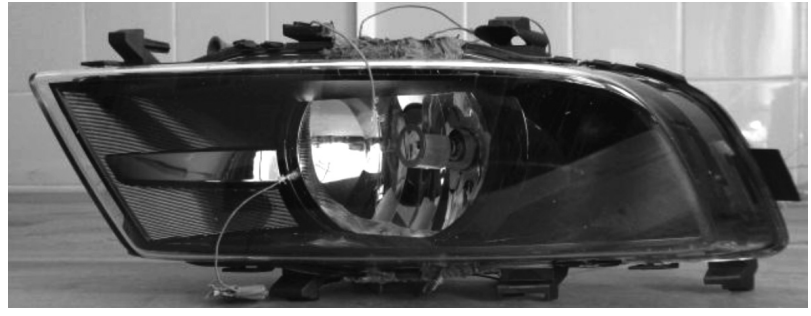

Figure 1: Lamp with thermocouples, front view

Slika 1: Žaromet s termoelementi, pogled od spredaj

wire thermocouples were used). The built-in, non-volatile memory stores up to 100 complete switch patterns. Then, the signal from the switcher is transferred through a GPIB cable into a Model 2000 multimeter made by the same company. Model 2000 is a high-performance digital multimeter, which can measure $\mathrm{DC}$ voltage, AC voltage, DC current, AC current, two- and four-wire resistance, and temperature. A thermocouple card is placed at a built-in cold junction. The final step is to save the data as a .txt file.

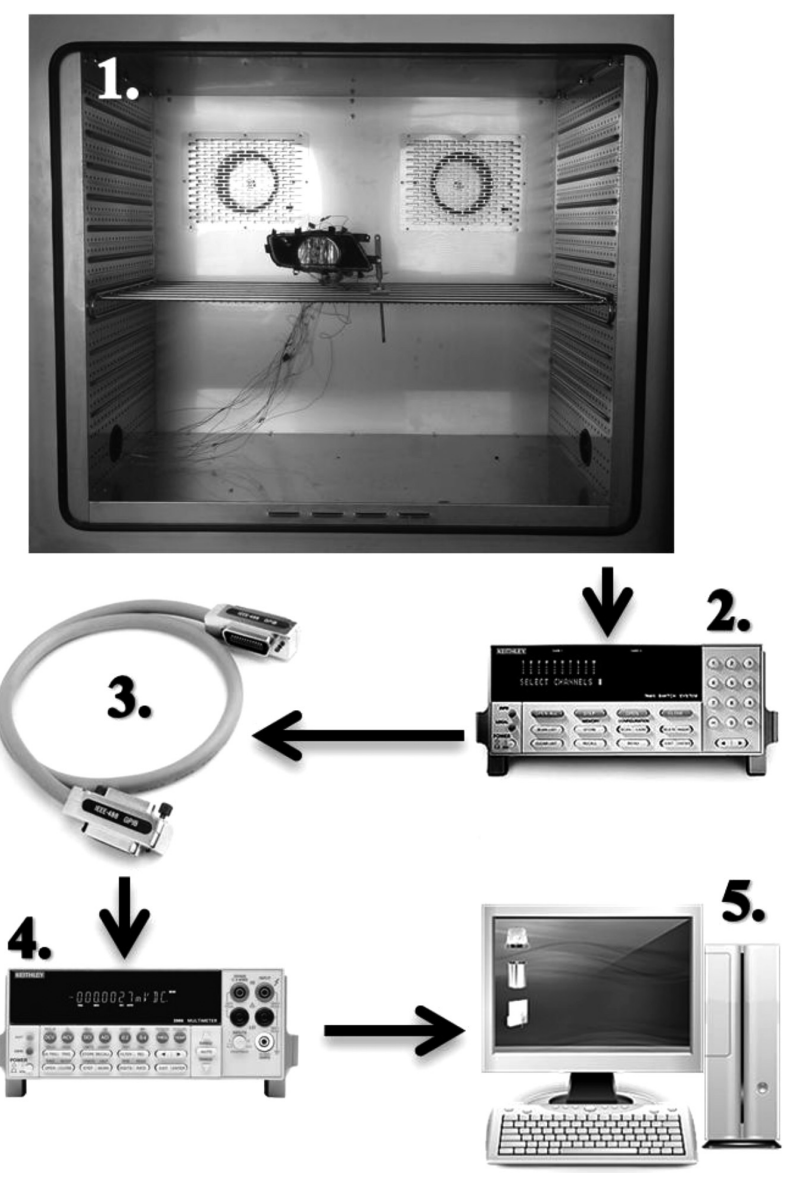

Figure 2: Data collection in the measurement circuit: 1) environmental simulation chamber with a lamp, 2) switcher, 3) GPIB cable, 4) multimeter and 5) computer

Slika 2: Zbiranje podatkov v merilnem tokokrogu: 1) simulacijska komora okolja z žarnico, 2) preklopnik, 3) GPIB-kabel, 4) multimeter in 5) računalnik

\subsection{Assembly of the thermocouples}

Measurement points (the locations of the thermocouples) were chosen based on the simulation results from two cross-sections, A and B (Figure 3). At these points, 1-mm-diameter holes were drilled to a depth of $1 \mathrm{~mm}$. The junction of a wire thermocouple was embedded into to this hole and filled with a high-temperature-resistant epoxy (Figure 4a). The operational temperature range of this epoxy is from $-55{ }^{\circ} \mathrm{C}$ to $180{ }^{\circ} \mathrm{C}$, and its thermal properties are similar to PP GF30, the plastic material used for the body of the lamp. If the hole for the thermocouple is made into a transparent material (such as the glass of a lamp), an epoxy with the same optical properties must be used due to transmittance (Figure $4 \mathbf{b}$ ). Using a material with different properties has a negative effect on the temperature measurement near the built-in thermocouple. A K-type thermocouple was used to record the data. This type is the most common general-purpose thermocouple, with a sensitivity of approximately $41 \mu \mathrm{V} /{ }^{\circ} \mathrm{C} .{ }^{4} \mathrm{~K}$-type thermocouples are recommended for use in oxidizing or completely inert atmospheres in a temperature range of $-200{ }^{\circ} \mathrm{C}$ to $1260{ }^{\circ} \mathrm{C}$. The positive wire consists of $90 \%$ nickel and $10 \%$ chromium, while the negative wire is consists of $95 \%$ nickel and $5 \%$ aluminum and silicon. ${ }^{4}$

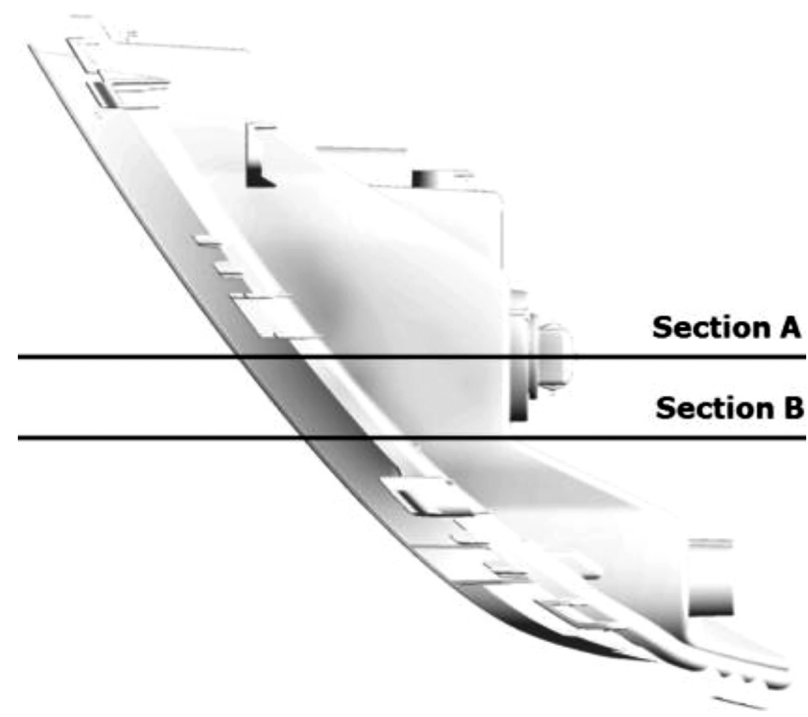

Figure 3: Top view of cross-sections A and B. Cross-section A is situated in the axis of the bulb filament, cross-section B is offset by 30 $\mathrm{mm}$ from section $\mathrm{A}$, in the $\mathrm{Y}$-axis direction.

Slika 3: Pogled od zgoraj na preseka A in B. Presek A je v osi žarilne nitke žarnice, presek B je zamaknjen za $30 \mathrm{~mm}$ od preseka A, v smeri Y-osi

Table 1: Thermal properties of lamp materials

Tabela 1: Toplotne lastnosti materialov žarometa

\begin{tabular}{|c|c|c|c|}
\hline Materials & $\begin{array}{c}\text { Density } \\
\left(\mathrm{kg} \mathrm{m}^{-3}\right)\end{array}$ & $\begin{array}{c}\text { Thermal } \\
\text { conductivity } \\
\left(\mathrm{W} \mathrm{m}^{-1} \mathrm{~K}^{-1}\right)\end{array}$ & $\begin{array}{c}\text { Specific heat } \\
\left(\mathrm{J} \mathrm{kg}^{-1} \cdot \mathrm{K}^{-1}\right)\end{array}$ \\
\hline Body PP GF30 & 1066 & 0.3 & 1351 \\
\hline Glass PMMA & 1194 & 0.33 & 1288 \\
\hline
\end{tabular}



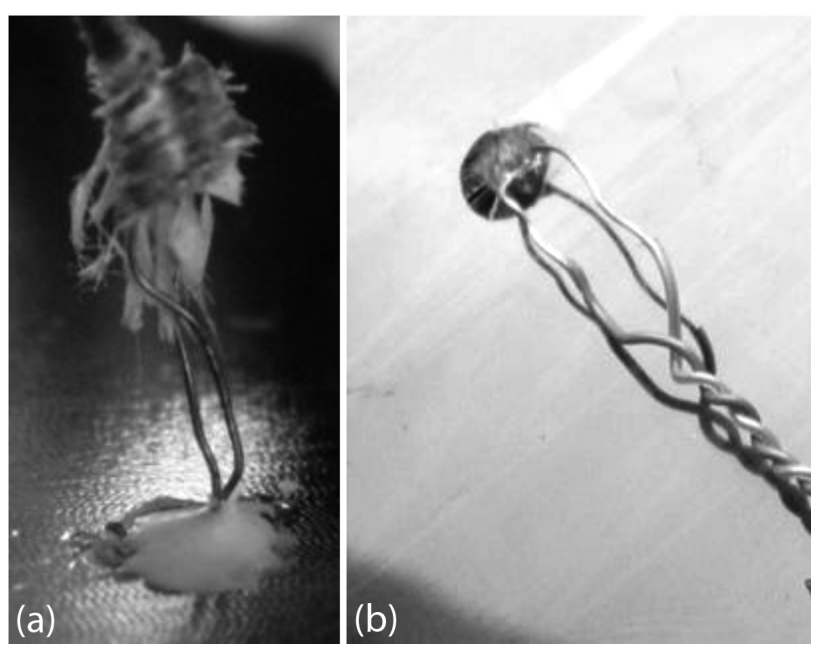

Figure 4: Thermocouple attachment: a) a normal surface and b) a transparent surface

Slika 4: Pritrditev termoelementa: a) je normalna površina, b) prozorna površina

\subsection{Calibration}

Each thermocouple had to be calibrated before the first measurement to obtain accurate results. This is due to the fact that thermocouples do not always have exactly the same characteristics, even if they meet fairly strict standards and tolerances. Calibration represents a deviation between the thermocouple measurement and a precise etalon. For a K-type thermocouple and a temperature range from $-40{ }^{\circ} \mathrm{C}$ to $375{ }^{\circ} \mathrm{C}$, the tolerance is $\pm 1.5^{\circ} \mathrm{C}$ (the highest class of accuracy). All the thermocouples had a deviation under the tolerance value. The tolerance of thermoelectric voltage $\mathrm{U}$ is determined with the following Equation (1): ${ }^{5}$

$$
\Delta U_{\mathrm{T}}=\Delta T \cdot\left(\frac{d U_{\mathrm{T}}}{d T}\right)
$$

where $\Delta U_{\mathrm{T}}$ is the thermoelectric voltage tolerance, $\Delta T$ is the temperature difference $\left({ }^{\circ} \mathrm{C}\right), T$ is the temperature $\left({ }^{\circ} \mathrm{C}\right)$, and $U_{\mathrm{T}}$ is the thermoelectric voltage $(\mathrm{V})$.

\section{LAMP SIMULATION}

Predictions of the temperatures of the lamps were computed with computational fluid dynamics (CFD). The CFD process consists of three important steps: pre-processing, solving, and post-processing.

\subsection{Pre-processing}

The geometry of the lamp was imported from raw CAD data. The next step was to create a computation mesh. The CutCell meshing method (Figure 5) in ANSYS TGrid 14.5 was used for this purpose. This method was chosen because its preparation time is shorter than the times needed for conventional

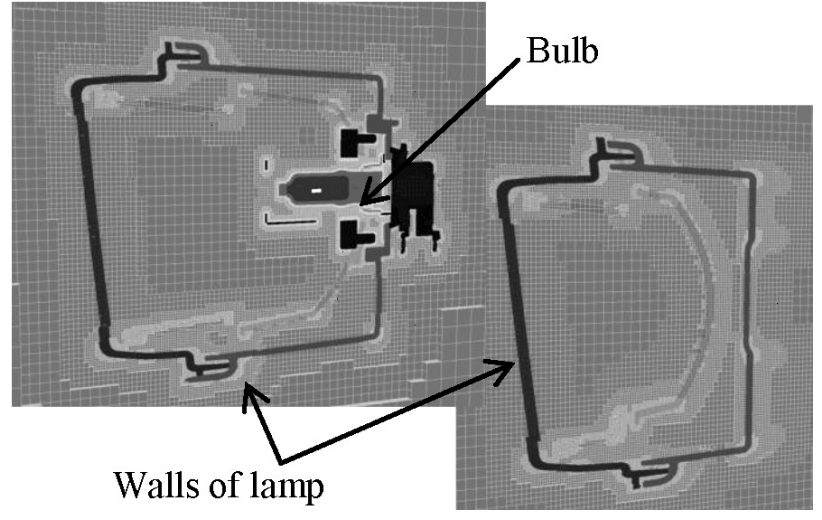

Figure 5: Example of the CutCell meshing method Slika 5: Primer mreže pri CutCell metodi

approaches. The size of the mesh was about 13 million polyhedral cells and the average size of these cells was 1 $\mathrm{mm}$.

\subsection{Solving}

The resulting mesh was exported into the ANSYS Fluent 14.5 solver, where appropriate boundary conditions were set up. These boundary conditions included the type of fluid flow (laminar), the material properties, the emissivity of the surfaces, the heat source, and, eventually, the forced convection around the lamp (simulating an environment as similar as possible to the climate chamber).

The distribution of temperatures inside the lamp depended mainly on natural convection (incompressible ideal gas) and radiation of the heat from the bulb. The heat absorbed by the surfaces was transported through the materials by heat conduction. The DO (discrete ordinate) model was used to model the radiation, allowing a calculation for semi-transparent walls.

The DO model uses a discretization technique, which solves the radiation-transfer equations for a finite number of angles or directions. The angular discretization is controlled by either increasing or decreasing the amount of theta-phi divisions and pixels. ${ }^{6}$ The number of divisions and pixels should therefore be kept at a minimum in order to keep computational costs as low as possible, but the minimum amount will also give the coarsest discretization. The settings vary between a minimum of $3 \times 3 \times 3 \times 3$, which is the coarsest, to $10 \times 10 \times 10 \times 10$, which is the maximum and gives the highest accuracy and finest discretization. Since the maximum discretization requires a lot of computational time and data storage, the angular discretization used in the radiation model was determined to be $6 \times 6 \times 6 \times 6$, which was sufficient. The effect of solar radiation could be specified but was not used for this case.

The solver solves the mass, momentum, energy and radiative-transport equations throughout the whole domain. The equations are discretized along the cells of the domain and solved until convergence is reached. 
M. GUZEJ, J. HORSKY: EXPERIMENTAL VERIFICATIONS AND NUMERICAL THERMAL SIMULATIONS ...
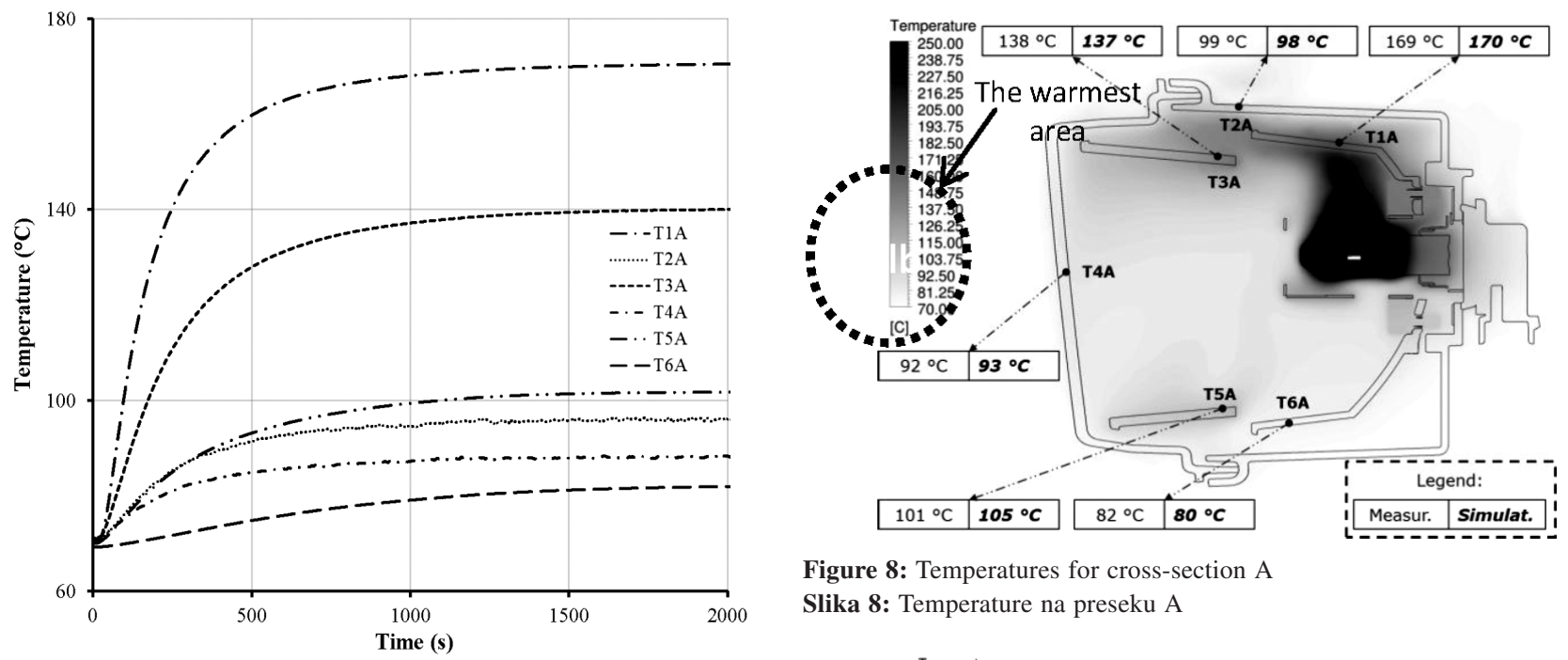

Figure 8: Temperatures for cross-section A Slika 8: Temperature na preseku A

Figure 6: Results for cross-section A

Slika 6: Rezultati iz preseka A

\subsection{Post-processing}

The results from the solution were visualized with plotting parameters of interest for every part, in our case focusing mainly on the temperatures. Post-processing was performed in ANSYS CFD-Post.

\section{MEASURED DATA}

The following two diagrams (Figures 6 and 7) show recorded temperatures of the lamp during the experiment for an ambient temperature of $70{ }^{\circ} \mathrm{C}$, a bulb supply voltage of $13.2 \mathrm{~V}$ and a sampling frequency of $5 \mathrm{~s}$.

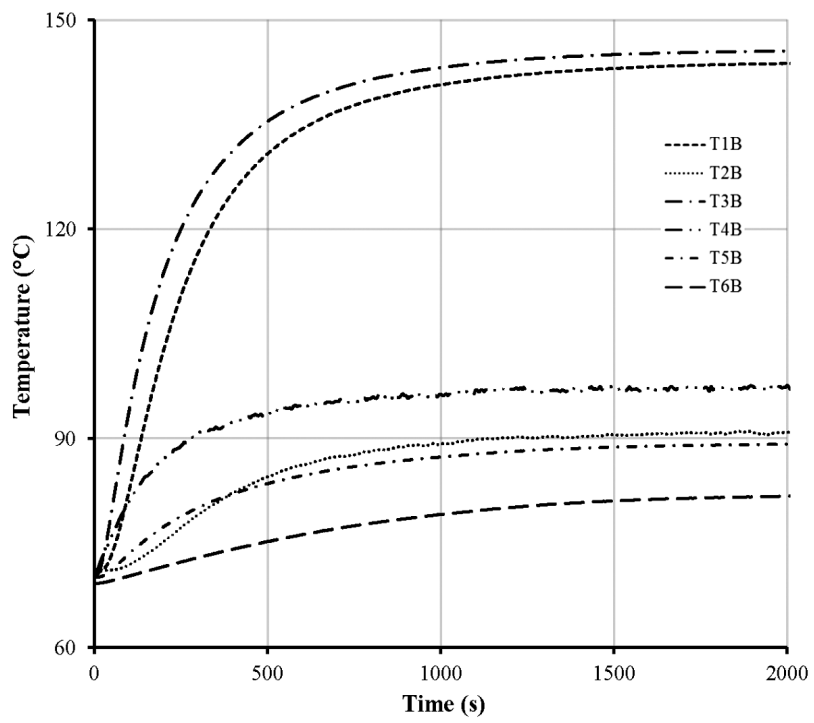

Figure 7: Results for cross-section B

Slika 7: Rezultati iz preseka B

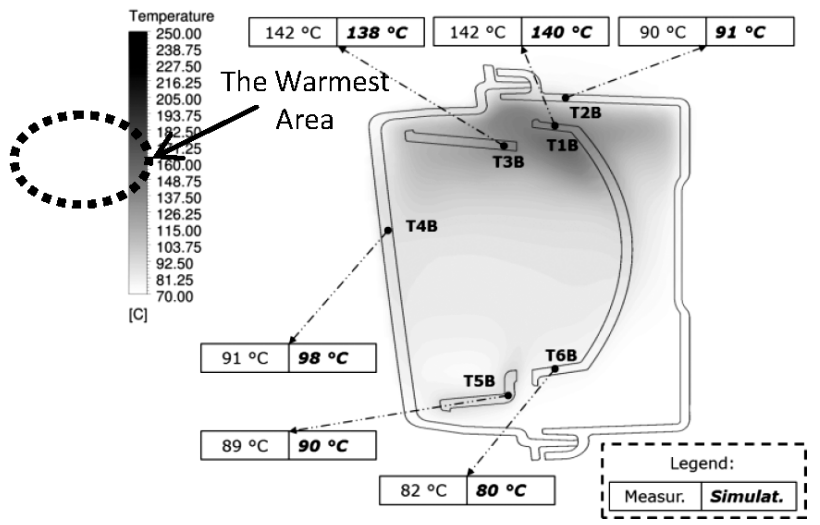

Figure 9: Temperatures for cross-section B

Slika 9: Temperature na preseku B

\section{DISCUSSION}

Figures $\mathbf{8}$ to $\mathbf{1 0}$ show a comparison between the numerical and experimental results (the temperature distributions were plotted for two cross-sectional points, A and B), including a bar graph showing the variation between the measurement and the simulation.

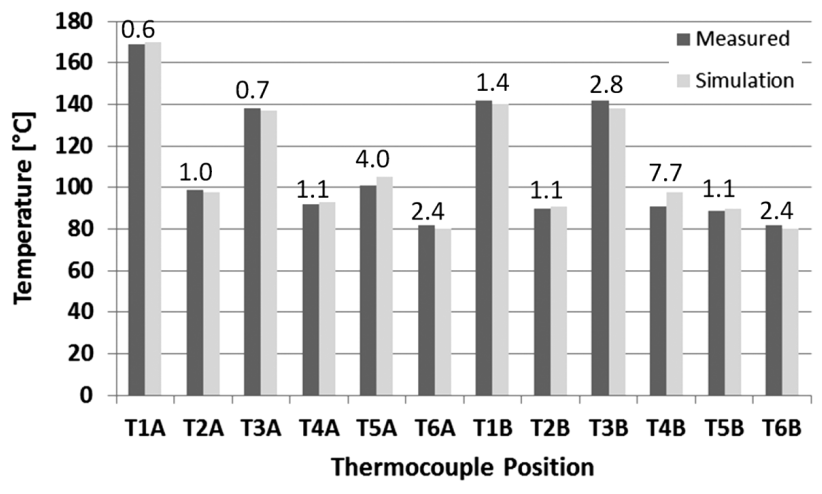

Figure 10: Comparison of the temperatures between the measurement and simulation

Slika 10: Primerjava izmerjenih in simuliranih temperatur 
The numbers at the top of the columns are percent deviations between the measured and simulated values for all the positions of the thermocouples.

\section{CONCLUSIONS}

This paper demonstrated the importance of a comparison between an experiment and a numerical simulation due to the unknown boundary conditions at the walls of real lamps. Determining an acceptable accuracy is necessary to verify the lamp model. The greatest deviations in the data are found for the T5A thermocouples (the simulated value is $4 \%$ above the measured value) and the T4B thermocouples (the simulated value is $7.7 \%$ above the measured value). Possible reasons for these inaccuracies are slightly different positions of the drilled holes and the control point from the ones used in the simulation, and the air flow around the lamp during the experiment, which had a higher (or lower) speed than the value calculated with the simulation.

\section{Acknowledgement}

This work is an output of the research and scientific activities of the NETME Centre, regional R\&D centre built with the financial support from the Operational Programme Research and Development for Innovations, carried out within a NETME Centre project (New
Technologies for Mechanical Engineering), Reg. No. CZ.1.05/2.1.00/01.0002 and, in the follow-up sustainability stage, supported through NETME CENTRE PLUS (LO1202) with the funds from the Ministry of Education, Youth and Sports under the National Sustainability Programme I.

\section{REFERENCES}

${ }^{1}$ V. A. Drebushchak, Universality of the emf of thermocouples, Thermochimica Acta, 496 (2009) 1-2, 50-53, doi:10.1016/j.tca.2009.06. 025

${ }^{2}$ T. Shiozawa, Thermal air flow analysis of an automotive headlamp: the PIV measurement and the CFD calculation for a mass production model, JSAE Review, 22 (2001) 2, 245-252, doi:10.1016/S03894304(00)00111-9

${ }^{3}$ K. Sokmen, K. Furkan, E. Pulat, N. Yamankaradeniz, S. Coskun, Thermal computations of temperature distribution and bulb heat transfer in an automobile headlamp, Heat and Mass Transfer, 50 (2014) 2, 199-210, doi:10.1007/s00231-013-1229-5

${ }^{4}$ Thermocouples, Sponsored by ASTM Committee E-20 on Temperature Measurement and Subcommittee E20.04 on Thermocouples, Manual on the use of thermocouples in temperature measurement, 6th ed., American Society for Testing and Materials, Philadelphia 1992

${ }^{5}$ J. H. Zhao, B. Zhou, Thermocouple Automatic Verifying Device Based on Virtual Instrument Technology, Applied Mechanics and Materials, 303-306 (2013), 588-596, doi:10.4028/www.scientific.net/AMM.303-306.588

${ }^{6}$ ANSYS Fluent Theory Guide, release 14.0., ANSYS Inc., 2011 